\title{
CORRIGENDUM
}

\section{Levels of glucocorticoid receptor and its ligand determine sensitivity and kinetics of glucocorticoid-induced leukemia apoptosis}

G Gruber, M Carlet, E Türtscher, B Meister, JAE Irving, C Ploner and R Kofler

Leukemia (2009) 23, 827; doi:10.1038/leu.2009.35

Correction to: Leukemia (2009) 23, 820-823;

doi:10.1038/leukemia.2008.360; published online 8 January 2009

Since the publication of this paper, the authors have noticed that the acknowledgements were omitted from the paper.

The acknowledgements are shown here.

\section{Acknowledgements}

We thank Dr S Geley for stimulating discussions, and A Kofler, S Lobenwein and L Minto for technical assistance. Supported by grants from the Austrian Science Fund (SFB-F021, P18747, P18571), the Austrian Ministry for Education, Science and Culture (GENAU-Ch.I.L.D.) and the 'Tyrolean Cancer Aid Society'.

The authors would like to apologize for this error. 